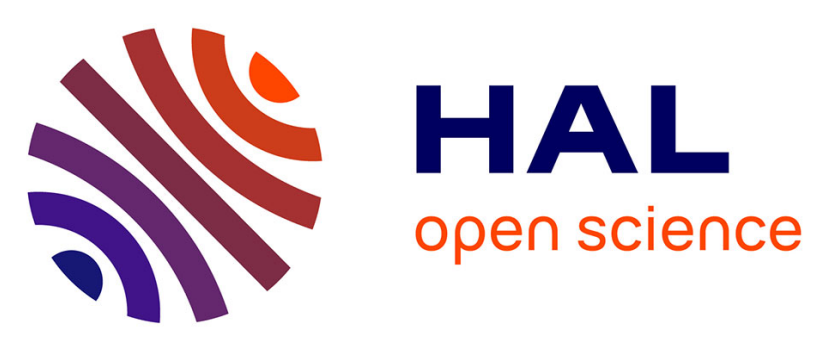

\title{
Synthesis of amidoximated polyacrylonitrile fibers and its use as adsorbent for Cr (VI) ions removal from aqueous solutions
}

Hayat Bouchoum, Dounia Benmoussa, Amane Jada, Mohamed Tahiri, Omar Cherkaoui

\section{To cite this version:}

Hayat Bouchoum, Dounia Benmoussa, Amane Jada, Mohamed Tahiri, Omar Cherkaoui. Synthesis of amidoximated polyacrylonitrile fibers and its use as adsorbent for $\mathrm{Cr}$ (VI) ions removal from aqueous solutions. Environmental Progress \& Sustainable Energy, 2019, 38, 10.1002/ep.13196 . hal-03046863

\section{HAL Id: hal-03046863 https://hal.science/hal-03046863}

Submitted on 9 Dec 2020

HAL is a multi-disciplinary open access archive for the deposit and dissemination of scientific research documents, whether they are published or not. The documents may come from teaching and research institutions in France or abroad, or from public or private research centers.
L'archive ouverte pluridisciplinaire HAL, est destinée au dépôt et à la diffusion de documents scientifiques de niveau recherche, publiés ou non, émanant des établissements d'enseignement et de recherche français ou étrangers, des laboratoires publics ou privés. 


\title{
Synthesis of Amidoximated Polyacrylonitrile Fibers and its Use as Adsorbent for Cr (VI) Ions Removal from Aqueous Solutions
}

\author{
Hayat Bouchoum $\odot$, ${ }^{a, b}$ Dounia Benmoussa, ${ }^{b}$ Amane Jada, ${ }^{c, d}$ Mohamed Tahiri, ${ }^{a}$ and Omar Cherkaoui ${ }^{b}$ \\ ${ }^{a}$ Faculty of Science Ain Chok, Laboratory of Geosciences, Hassan II University, Geology department, Casablanca, Morocco; bouchoum. \\ hayat@gmail.com (for correspondence) \\ ${ }^{\mathrm{b}}$ Higher School of Textile and Clothing Industries, Laboratory REMTEX, Casablanca, Morocco \\ 'Université de Haute-Alsace, CNRS, IS2M, UMR7361, F-68100, Mulhouse, France \\ ${ }^{\mathrm{d} U n i v e r s i t e ́ ~ d e ~ S t r a s b o u r g, ~ S t r a s b o u r g, ~ F r a n c e ~}$
}

Published online 28 February 2019 in Wiley Online Library (wileyonlinelibrary.com). DOI 10.1002/ep.13196

Functionalized fibers, especially polyacrylonitrile fibers (PANF), have attracted wide interest as an effective and economical material for environment and water protection. In this study, polyacrylonitrile fibers modified with bydroxylamine bydrochloride were used as an adsorbent to remove hexavalent chromium ions from aqueous solutions. The novelty of the present study compared to the literature is the functionalization of polyacrylonitrile fibers surface by optimizing cost and energy while achieving a yield fast removal rate and bigh adsorption capacity of hexavalent chromium from aqueous solutions. The amidoximated polyacrylonitrile fibers were characterized using Fourier Transform InfraRed spectroscopy (FTIR) and Scanning Electron Microscopy (SEM). The results confirmed the success of polyacrylonitrile fibers modification. The adsorption capacity was evaluated by investigating the effect of initial pH solution ranging from 2.0 to 7.0 , the adsorbent dose varied from 0.05 to $0.25 \mathrm{~g}$, the initial $\mathrm{Cr}$ (VI) concentration range was (5-70 $\mathrm{mg} \mathrm{g}^{-1}$ ), the temperature varied from 5 to $60^{\circ} \mathrm{C}$, and the contact time ranged from $O$ to $180 \mathrm{~min}$. We have used the Langmuir and Freundlich adsorption models to describe the equilibrium sorption data. The maximum adsorption capacity estimated using the Langmuir model reached $32.57 \mathrm{mg} \mathrm{g}^{-1}$ under optimal conditions. The thermodynamic parameters $(\Delta G, \Delta H$, and $\Delta S$ ) were also determined. In addition, the adsorbent showed a desorption rate of $\mathrm{Cr}$ (VI) up to $92 \%$ with $0.5 \mathrm{~mol}$ of $\mathrm{NaOH}$, which can be reused for three adsorption-desorption cycles. The overall data showed the efficiency of amidoximated polyacrylonitrile fibers in removing Cr (VI) from aqueous solutions. (C) 2019 American Institute of Chemical Engineers Environ Prog, 38: e13196, 2019

Keywords: wastewater treatment, adsorption, recycling, chromium (VI)

\section{INTRODUCTION}

The various uses of metals in industry, domestic, agricultural, medical, and technological applications, have caused their excessive release into various ecosystems. Their discharge into the

(C) 2019 American Institute of Chemical Engineers environment without appropriate treatment is hazardous for, both, the human health and the environmental ecosystems. Heavy metals are not biodegradable, they are highly soluble in water and tend to accumulate in living tissues [1]. Chromium pollution is one of the most important environmental concerns; it is released by various industrial processes such as electroplating, leather tanning, dyes and pigments synthesis, dyeing, cement, wood preservation, etc. [2]. In the environment, chromium ions generally take two stable oxidation states $\mathrm{Cr}$ (III) and $\mathrm{Cr}$ (VI). The $\mathrm{Cr}$ (III) ion is a micronutrient which is essential for human health, whereas Cr (VI) ion is a primary contaminant which is very irritating and it is 500 times more toxic than trivalent chromium ion [3]. Furthermore, $\mathrm{Cr}(\mathrm{VI})$ is listed in group A of toxic pollutants in wastewater by the Environmental Protection Agency (EPA) [4]. $\mathrm{Cr}$ (VI) species may exist in wastewater as chromates $\left(\mathrm{CrO}_{4}{ }^{2-}\right)$, dichromate $\mathrm{Cr}(\mathrm{VI})\left(\mathrm{Cr}_{2} \mathrm{O}_{7}{ }^{2-}\right)$ and bichromate $\left(\mathrm{HCrO}_{4}{ }^{2-}\right)$, depending on the $\mathrm{pH}$ and the $\mathrm{Cr}$ (VI) concentration [5]. Exceeding the limit, he cause skin and stomach irritation for a short-time exposure and damage to liver, and death in large doses for a long-time exposition [6]. Hence, according to the world health organization (WHO), the maximum level of chromium in drinking water, in land surface water and industrial wastewater is $0.05,0.1$ and $0.25 \mathrm{mg} \mathrm{L}^{-1}$, respectively [7]. The Environmental Protection Agency recommended the maximum permissible concentration of chromium in drinking water into $0.1 \mathrm{mg} \mathrm{L}^{-1}$ [8]. Accordingly, the wastewater contaminated by $\mathrm{Cr}$ (VI) should be treated and reduced to permissible levels before their release into the environment.

According to the literature, methods such as chemical precipitation, electrochemical process, ion exchange, reverse osmosis, membrane separation, and cementation [9] are used to remove hexavalent chromium species from wastewater. However, all these techniques include high operating cost, high energy consumption, low throughput, low selectivity, toxic sludge generation, and maintenance problems [10]. Adsorption process, on the other hand, has the advantage of the effective and low-cost process, easy operational conditions, flexibility, low secondary pollution, and reusability [11]. The adsorption efficiency of an adsorbent is mainly depending on its surface functional groups. Nevertheless, the material uptake capacity (chemisorption) is not the important point, but also its ability to desorb subsequently 
metals (physisorption) [12]. Various adsorbents such as activated carbon, waste biomass, industrial waste, bio-sorbents, chitosan, and chelating materials, have been used to remove $\mathrm{Cr}$ (VI) from aqueous solutions [13-18]. Activated carbons, having powder or granular forms, are mostly used for heavy metal ions removal from wastewater. However, this adsorbent is expensive for a developing country and its selectivity is limited [19]. The adsorption capacity of $\mathrm{Cr}$ (VI) from aqueous solutions using biomass was evaluated by investigating various parameters. Jain et al. [14], have treated sun flower waste with sulfuric acid which was used as an adsorbent for $\mathrm{Cr}(\mathrm{VI})$ removal from water. According to this reported work, the maximum $\mathrm{Cr}$ (VI) adsorption was found to be $53 \mathrm{mg} \mathrm{g}^{-1}$ at $\mathrm{pH}$ 2.0. Rao et al. [16] found that the fruits of Ficusglomerata achieved a Cr (VI) adsorption capacity of $23.1 \mathrm{mg} \mathrm{g}^{-1}$ from wastewater. Natural cactus has also been used as an adsorbent for $\mathrm{Cr}$ (VI) removal $\left(21.19 \mathrm{mg} \mathrm{g}^{-1}\right)$ at optimal conditions [20]. Removal toxic metals from water by using an industrial waste have been also investigated. The olive oil factory waste pomace was studied to remove $\mathrm{Cr}$ (VI) from aqueous solutions [15], the adsorption amount was $19.58 \mathrm{mg} \mathrm{g}^{-1}$. Activated sludge biomass has been used and proved its ability to remove $\mathrm{Cr}$ (VI) from aqueous solutions with a total removal of $77 \%$ [21]. The use of bacteria for Cr (VI) removal has already been studied [22-24]. Recently, researchers evaluated the potential of nanoscale zero valence iron to remove $\mathrm{Cr}$ (VI). Fu et al [25] synthesized a resin supported nanoscale zero-valence iron by the borohydride reduction method and reached a removal efficiency of $84.4 \%$. Table 1 shows various low-cost adsorbents used in literature to remove $\mathrm{Cr}$ (VI) ions from aqueous solutions.

Among these adsorbents, polymer fibers are considered to be one of the efficient adsorbents used for wastewater treatment, removal and recovery of toxic metals [27]. Polyacrylonitrile fiber (PANF) is a commercial and cheap synthetic, semi-crystalline organic polymer [28], applied to develop a wide range of products such as carbon fibers [29], catalysts [30], protective and biomedical materials [31], composite materials [32], filtration and ultrafiltration membrane [33], heavy metals sensors and adsorbents [34], and conductive materials [35]. Due to their strong chemical resistance, excellent mechanical properties, good thermal stability, resistance to corrosion and solvent, low flammability and commercial viability, PANF is one of the most favorable polymer fibers for heavy metals removal from aqueous solutions [33]. Compared to the traditional adsorbents, PANF reaches a high adsorption capacity with a low-cost process and fast adsorption equilibrium due to the large surface area which is five times larger than porous beads [27] and the shorter diffusional distance, it is also easily recovered and easy to separate [28]. The production technology of chelating fibers is simple, easier and can produce various shapes which can be used in several applications. Moreover, the nitrile group, which has lone pair of electrons, strong polarity and triple bonds of carbon-nitrogen $(C \equiv N)$, is found profusely in PANF surface and can be easily transformed into a number of functionalities (Carboxyl, amide, amine, amidoxime, tetrazine, phosphoric, etc.) [36]. The amidoxime group has been found to be effective for heavy metals removal from aqueous solutions [37]. However, in developing countries, the process needs to be based on lower cost technologies and should simultaneously offer attractive, efficient and eco-friendly options for $\mathrm{Cr}$ (VI) removal.

In the present study, amidoximated polyacrylonitrile fibers (AO-PANF) were prepared through a one-step reaction of polyacrylonitrile fibers with hydroxylamine hydrochloride in aqueous solutions. The AO-PANF was used as an adsorbent to remove $\mathrm{Cr}$ (VI) from aqueous solutions. The effects of various parameters on Cr (VI) adsorption such as the initial pH solution, the adsorbent dose, the initial Cr (VI) concentration, the temperature and the contact time, are discussed. In addition, the desorption of the adsorbed $\mathrm{Cr}$ (VI) ions from the (AO-PANF) was also investigated.
Table 1. Comparison of $\mathrm{Cr}$ (VI) adsorption capacity by different adsorbents.

\begin{tabular}{|c|c|c|}
\hline Adsorbents & $q\left(\mathrm{mg} \cdot \mathrm{g}^{-1}\right)$ & References \\
\hline Carbonaceous & 53.76 & [14] \\
\hline Apple peels & 36.01 & [26] \\
\hline Ficusglomerata & 23.1 & [16] \\
\hline Cactus & 21.9 & {$[20]$} \\
\hline Pomace & 18.69 & {$[15]$} \\
\hline Dried biomass & 17.61 & {$[21]$} \\
\hline Polyacrylonitrile fibers & 32.57 & Present study \\
\hline
\end{tabular}

\section{MATERIALS AND METHODS}

\section{Material and Instrumentation}

Commercial polyacrylonitrile fibers (PANF) was cut, washed with distillated water and dried in an oven. The chelating agent, Hydroxylamine hydrochloride, with purity $\geq 99 \%$ was purchased from Scharlab. Potassium dichromate, purity: 99\%, was provided from Riedel-de Haen and used as received. $\mathrm{NaOH}$ and $\mathrm{HCl}$, were used to adjust solutions $\mathrm{pH}$.

Fourier Transform InfraRed (FTIR) spectroscopy analysis of PANF samples was obtained using the Thermo Scientific ${ }^{\mathrm{TM}}$ Nicolet $^{\mathrm{TM}}$ iS ${ }^{\mathrm{TM}} 10$ FT-IR spectrometer at room temperature. The samples morphologies were evaluated using Scanning Electron Microscopy (SEM) analysis, using an FEI Quanta 400 ESEM equipped with the Everhart Thornley Detector (ETD) as a Secondary Electron (SE) detector, and Energy Dispersive X-ray detector, Oxford, INCA Instruments. The SEM was operating at electrical potentials ranging between 12.5 and $30 \mathrm{kV}$, and at working distance (WD) ranging between 9.1 and $11 \mathrm{~mm}$. The quantification of $\mathrm{Cr}$ (VI) concentration was determined using diphenyl carbazide by colorimetric method (3500-Cr.B, AWWA-APHA standard code), at $540 \mathrm{~nm}$ according to AFNOR standard T91/F under ThermoFisher Evolution ${ }^{\mathrm{TM}} 300 \mathrm{Uv}-\mathrm{Vis}$ spectrophotometer, at room temperature. The $\mathrm{pH}$ measurements were performed using a $\mathrm{pH}$ meter Thermo Scientific Orion 4 STAR.

\section{Adsorbent Preparation}

The PANF were treated with hydroxylamine hydrochloride under different reaction conditions. The chelating agent and PANF $(0.2 \mathrm{~g})$ were added to a flask which contains $50 \mathrm{~mL}$ of $\mathrm{NaOH}$ solution (methanol/water 5:1), and stirred. The reaction was carried out at $70^{\circ} \mathrm{C}$ [38] using different concentrations of hydroxylamine hydrochloride $(0.05-0.15 \mathrm{M})$ for various durations times (30-120 min). The final products were separated from solutions by filtration, and washed several times with distilled water/methanol mixture. Thereafter, the AO-PANF was dried in an oven at $60^{\circ} \mathrm{C}$ for 1 day (Figure 1).

The conversion of nitrile groups in PANF into amidoxime groups was evaluated according to Equation (1):

$$
C_{n} \frac{W_{1}-W_{0}}{W_{0}} \frac{M_{0}}{M_{1}} \times 100
$$

Where $C_{n}$ is \% percentage conversion of nitrile groups in PANF into amidoxime groups, $W_{0}$ is the weight of the PANF before reaction $(\mathrm{g}), W_{1}$ is the weight of PANF after reaction $(\mathrm{g})$, $M_{0}$ is the molecular weight of acrylonitrile monomer $\left(53 \mathrm{~g} \mathrm{~mol}^{-1}\right)$ and $M_{1}$ is the molecular weight of hydroxylamine $\left(33 \mathrm{~g} \mathrm{~mol}^{-1}\right)$.

\section{Chromium Adsorption Process}

Aqueous Cr (VI) solutions with initial concentrations range from 5 to $70 \mathrm{mg} \mathrm{L}^{-1}$ were prepared by dissolving appropriate amounts of potassium dichromate in distilled water. Aqueous $\mathrm{Cr}$ (VI) solution $(50 \mathrm{~mL})$ was shaken with AO-PANF at $150 \mathrm{rpm}$ under different conditions. After a while, the non adsorbed chromium ions present in the supernatant were separated from the aqueous solutions by filtration. 
(a)

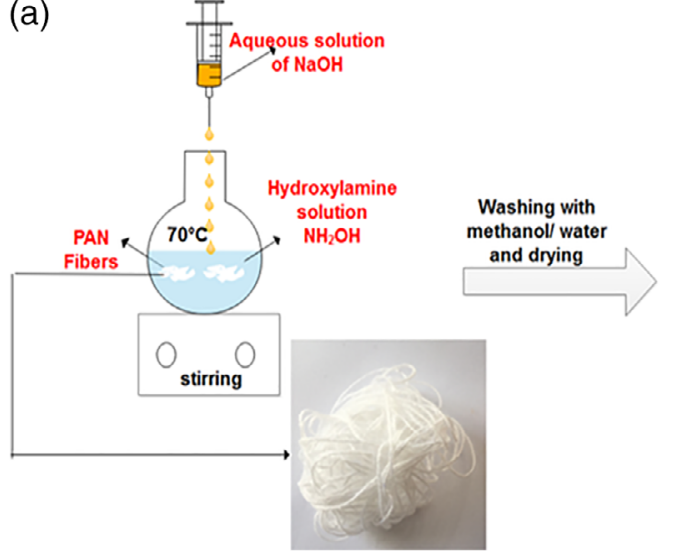

(b)

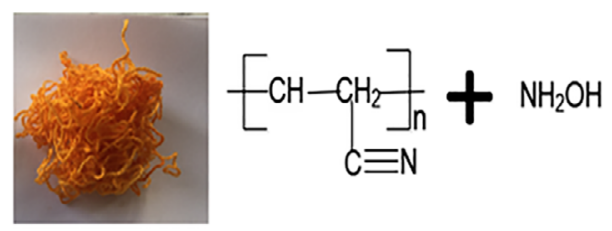

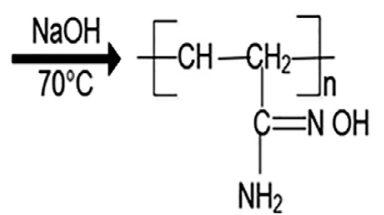

Figure 1. (a) Schematic illustration of AO-PANF synthesis and (b) the amidoximation reaction. [Color figure can be viewed at wileyonlinelibrary.com]

The effect of the initial $\mathrm{pH}$ solution on the $\mathrm{Cr}$ (VI) adsorption using AO-PANF was first studied by varying the $\mathrm{pH}$ from 2.0 to 7.0 using $0.1 \mathrm{M} \mathrm{NaOH}$ or $\mathrm{HCl}$ solutions. In addition, the optimum adsorbent dose was evaluated by varying the adsorbent dose in the range of $0.05-0.25 \mathrm{~g}$, at contact time of $1 \mathrm{~h}$, initial $\mathrm{Cr}$ (VI) concentration of $10 \mathrm{mg} \mathrm{L}^{-1}$ and $\mathrm{pH} 3.0$. The adsorption kinetics were conducted in $0-180$ min interval time at initial $\mathrm{Cr}$ (VI) concentrations of $10 \mathrm{mg} \mathrm{L}^{-1}, \mathrm{pH}=3.0$, using the optimum adsorbent dose. The effect of initial concentrations (5-70 $\mathrm{mg} \mathrm{L}^{-1}$ ) on $\mathrm{Cr}$ (VI) sorption was then evaluated by immersing the adsorbent with $50 \mathrm{~mL}$ of $\mathrm{Cr}(\mathrm{VI})$, at $25^{\circ} \mathrm{C}$, for $1 \mathrm{~h}$, in a constant rotating shaker, at $\mathrm{pH}$ 3.0. In addition, the influence of temperature $\left(5-60^{\circ} \mathrm{C}\right)$ was also studied.

The remaining concentration of $\mathrm{Cr}$ (VI) was measured by spectroscopy Uv-Visible at $\lambda_{\max }=540 \mathrm{~nm}$, using 1.5 diphenylcarbazide as a complexing agent which react with $\mathrm{Cr}$ (VI) and oxidizes into 1.5 diphenylcarbazone in acidic medium, resulting in formation of red-violet complex.

The removal efficiency of chromium ions $R(\%)$ and equilibrium adsorption capacity $\mathrm{q}\left(\mathrm{mg} \mathrm{g}^{-1}\right)$ was calculated as follows:

$\% R=\frac{C_{0}-C_{1}}{C_{0}} \times 100$

$q=V \frac{\left(C_{0}-C_{1}\right)}{W}$

Where $\% R$ is the removal efficiency, $q$ is the equilibrium adsorption capacity of the adsorbent $\left(\mathrm{mg} \mathrm{g}^{-1}\right), C_{0}$ and $C_{1}$ are, respectively, the initial and the final concentrations of $\mathrm{Cr}$ (VI) $\left(\mathrm{mg} \mathrm{L}^{-1}\right), \mathrm{V}$ is the volume of solution $(\mathrm{L})$ and $\mathrm{W}$ is the adsorbent weight $(\mathrm{g})$.

\section{Desorption Experiments}

After the adsorption, to study the ability to reuse the adsorbent, various desorbing solutions $\mathrm{NaOH}, \mathrm{NaCl}$, and $\mathrm{HCl}$ ) with a concentration of $0.5 \mathrm{M}$ were used to desorb $\mathrm{Cr}$ (VI) from the adsorbent. First, a given amount of the adsorbent $(100 \mathrm{mg})$ was mixed and shaked with $50 \mathrm{~mL}$ of $\mathrm{Cr}$ (VI) at optimum conditions. Cr (VI) was then desorbed using one of the desorbed solutions $(\mathrm{NaOH}, \mathrm{NaCl}$, and $\mathrm{HCl})$ for a period time of $16 \mathrm{~h}$ at $25^{\circ} \mathrm{C}$. After the desorption experiment, the adsorbent was recovered by filtration, washed with distilled water, dried, and reuse for the next adsorption-desorption cycle.

\section{RESULTS AND DISCUSSION}

\section{InfraRed Characterization}

FTIR spectra of raw and AO-PANF prepared with various $\mathrm{NH}_{2} \mathrm{OH} . \mathrm{HCl}$ concentrations are shown in Figure 2a. As can be seen in this figure, the raw PANF shows absorption peaks of nitrile group at $2242 \mathrm{~cm}^{-1}$, carboxylic group at $1737 \mathrm{~cm}^{-1}$ and hydrocarbons compounds at 1449 and $1234 \mathrm{~cm}^{-1}$ [37]. Further, the comparison of both raw and AO-PANF spectra under optimum conditions, as depicted in Figure 2a,b, indicates the effect of increase $\mathrm{NH}_{2} \mathrm{OH} . \mathrm{HCl}$ concentrations leads to the decrease of the nitrile group absorption peak. This result is in accordance with previous studies [39,40]. This decrease results from the conversion of nitrile groups to amidoxime groups, leading to the apparition of new absorption peaks occurring at 943 and $1650 \mathrm{~cm}^{-1}$ [41]. In addition, the amidoximation reaction which results in the formation of amide groups and carboxylic acid is characterized by absorption bands occurring at 1650 and $1562 \mathrm{~cm}^{-1}$, respectively [37]. Consequently, the FTIR spectra comparison of the raw and the AO-PANF brings forth evidence that the PANF functionalization reaction took place.

The effect of the adsorption process on the AO-PANF is shown in Figure 2c. The comparison between the AO-PANF before and after adsorption shows that the chromium adsorption on the adsorbent surface, in the main, does not alter the initial structure of the modified adsorbents, with a small change in the intensity of carboxylic acid spectrum.

\section{Influence of Reaction Time and $\mathrm{NH}_{2} \mathrm{OH} . \mathrm{HCl}$ Concentrations on the PANF Functionalization}

The influence of reaction conditions such as the reaction time and the $\mathrm{NH}_{2} \mathrm{OH} . \mathrm{HCl}$ concentrations on the PANF modification were investigated. Figure 3 indicates the effects of $\mathrm{NH}_{2} \mathrm{OH} . \mathrm{HCl}$ concentrations and the reaction time on the PANF amidoxime group contents. As can be seen in Figure $3 \mathrm{a}$, the conversion of PANF nitrile groups into amidoxime group increased as the concentration of $\mathrm{NH}_{2} \mathrm{OH} . \mathrm{HCl}$ and the reaction time increased (Figure 3b). The conversion of nitrile groups can be explained by the high diffusion of $\mathrm{NH}_{2} \mathrm{OH}$ from solution into the fibers, as resulting from the increase of $\mathrm{NH}_{2} \mathrm{OH} . \mathrm{HCl}$ concentration and/or the reaction time. To save energy and to keep good fibers properties, $0.15 \mathrm{M}$ of $\mathrm{NH}_{2} \mathrm{OH} . \mathrm{HCl}$ at $70^{\circ} \mathrm{C}$ for $1 \mathrm{~h}$ can be selected as the optimum experimental conditions for the modification of PANF.

\section{SEM Photographs}

The morphologies of the raw PANF, AO-PANF, and AO-PANF after $\mathrm{Cr}$ (VI) adsorption are shown in Figure 4. The raw PANF has smooth and uniform surface (Figure $4 \mathrm{a}$ ). The comparison between raw and AO-PANF shows that the fibers surface after modification becomes rougher and corroded (Figure 4b). The adsorption of chromium ions are obvious, as can be seen in the Figure 4c. The SEM photographs show that the fibers diameter after modification remains unchanged. 
(a)

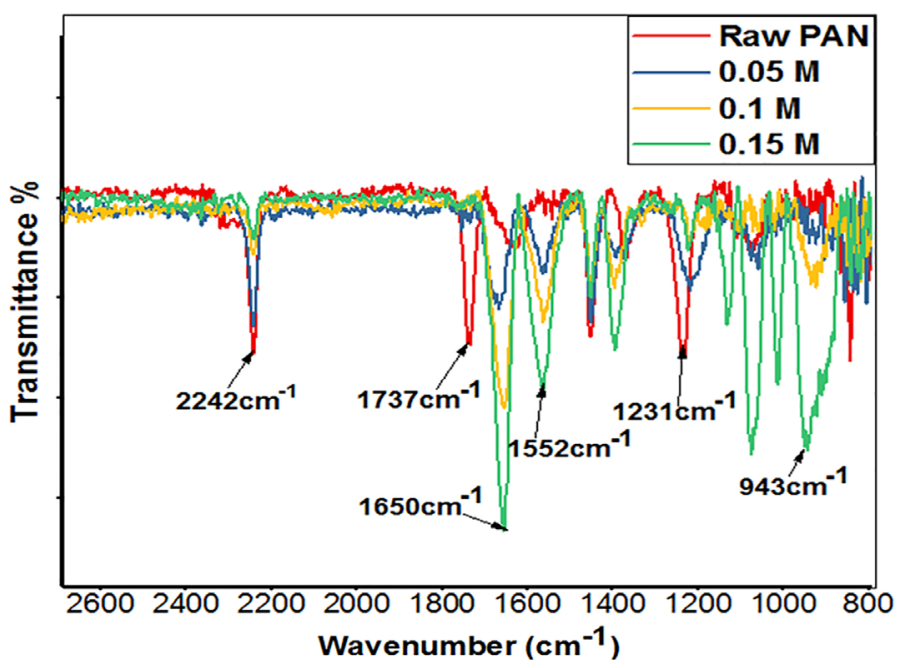

(b)

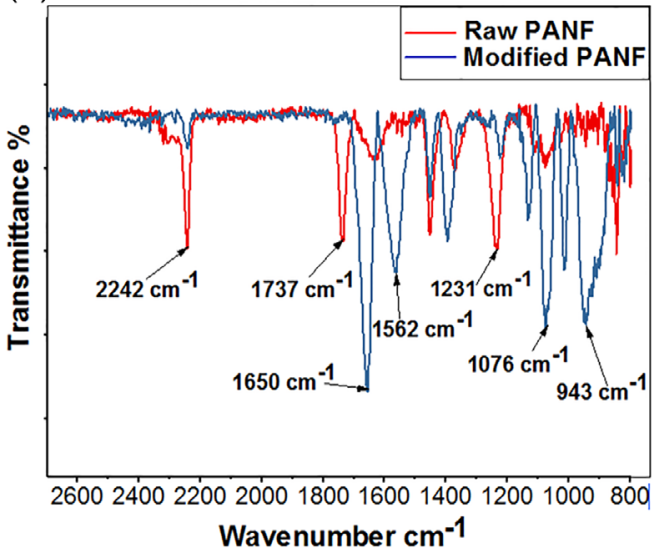

(c)

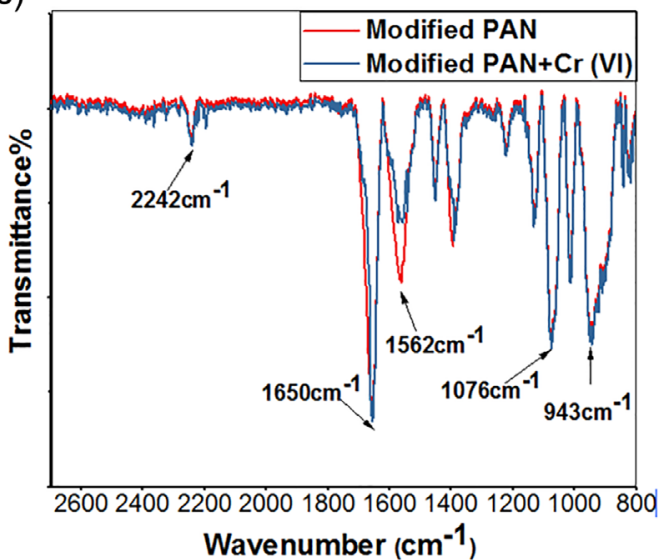

Figure 2. (a) FTIR spectra of raw and AO-PANF at different concentrations of $\mathrm{NH}_{2} \mathrm{OH} . \mathrm{HCl}(0.05-0.15 \mathrm{M})$ for a reaction time of $1 \mathrm{~h}$, (b) under optimum conditions, and (c) after adsorption. [Color figure can be viewed at wileyonlinelibrary.com]
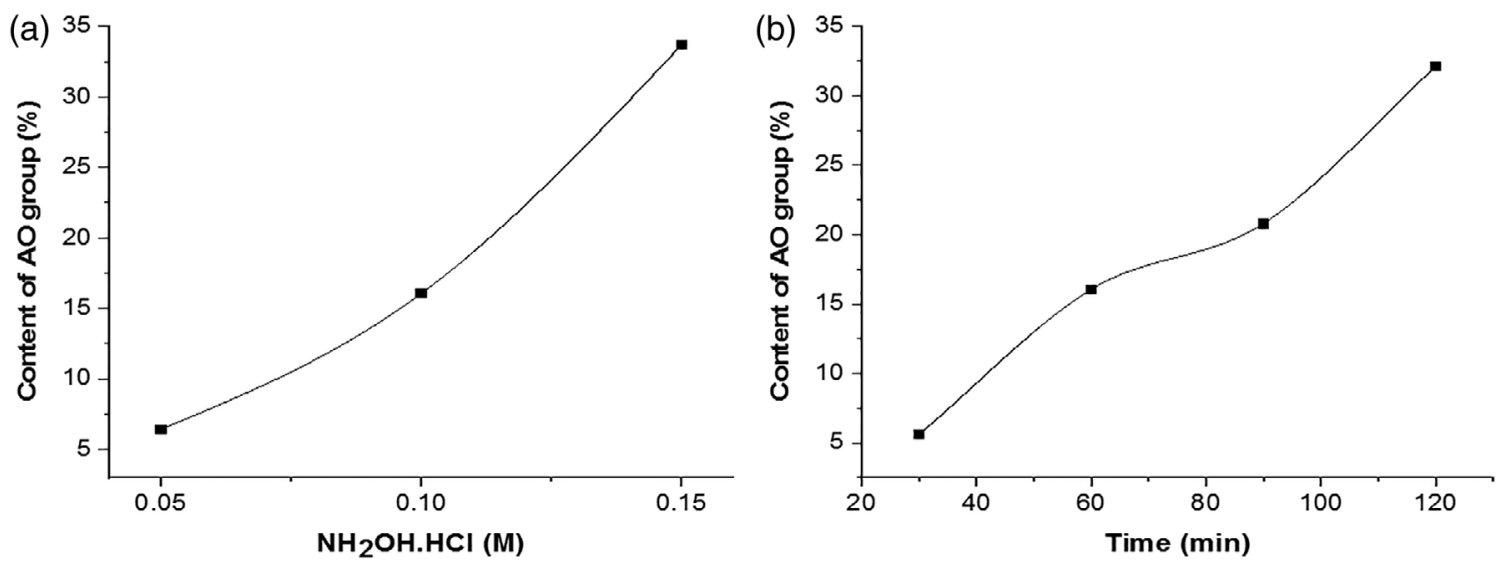

Figure 3. (a) Influence of $\mathrm{NH}_{2} \mathrm{OH} . \mathrm{HCl}$ concentrations, (b) duration time on the content of amidoxime groups in AO-PANF. Experimental conditions: $T=70^{\circ} \mathrm{C}$, contact time $=1 \mathrm{~h}, \mathrm{C}\left(\mathrm{NH}_{2} \mathrm{OH} \cdot \mathrm{HCl}\right)=0.1 \mathrm{M}$.

\section{Adsorption Mechanism}

Effect of $p H$

The effect of initial $\mathrm{pH}$ solutions on $\mathrm{Cr}$ (VI) adsorption (Figure 5) from aqueous solutions onto AO-PANF was investigated by ranging $\mathrm{pH}$ from 2.0 to 7.0 , at room temperature, with an initial $\mathrm{Cr}$ (VI) concentration $10 \mathrm{mg} \mathrm{L}^{-1}$, using $0.1 \mathrm{~g}$ of adsorbent dose. The initial solution $\mathrm{pH}$ affects mainly not only the chromium speciation in solution but also the surface charge of the adsorbent. In this study, the point zero charge of adsorbent $\mathrm{pH}_{\mathrm{PZC}}$ was determined through the $\mathrm{pH}$-drift method to evaluate the surface charge of adsorbent [42]. The $\mathrm{pH}_{\mathrm{PZC}}$ of AO-PANF is 3.9. When $1<\mathrm{pH}<3$, $\mathrm{Cr}$ (VI) exists as $\mathrm{HCrO}_{4}^{-}$form. At pH range of 3.0-6.0, chromium coexist as $\mathrm{Cr}_{2} \mathrm{O}_{7}{ }^{2-}$ and $\mathrm{HCrO}_{4}^{-}$, which is considered the predominant ions (80\%). For $\mathrm{pH}>6.0, \mathrm{CrO}_{4}{ }^{2-}$ dominates [43]. 
(a)

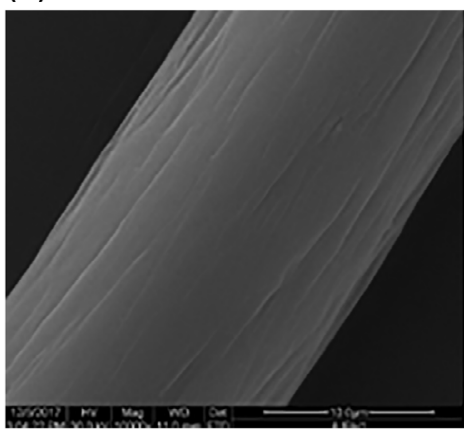

(b)

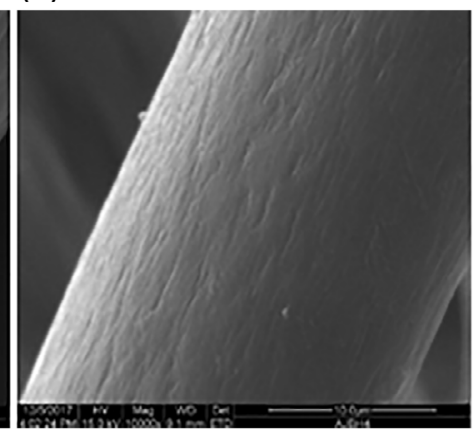

(c)

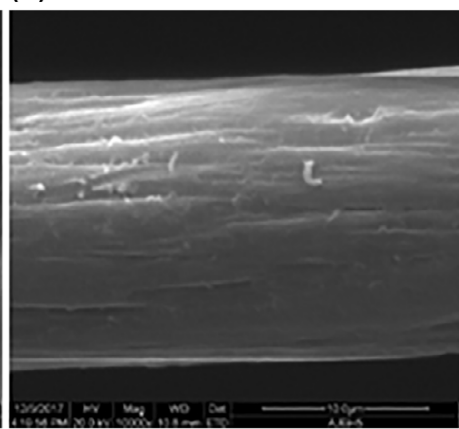

Figure 4. (a) SEM micrographs of the raw PANF, (b) AO-PANF before Cr (VI) adsorption, and (c) AO-PANF after Cr (VI) adsorption. Experimental conditions: $\mathrm{C}\left(\mathrm{NH}_{2} \mathrm{OH} \cdot \mathrm{HCl}\right)=0.15 \mathrm{M}, \mathrm{C}(\mathrm{Cr}(\mathrm{VI}))=10 \mathrm{ppm}, T=70^{\circ} \mathrm{C}$, contact time $\left.=1 \mathrm{~h}\right)$.
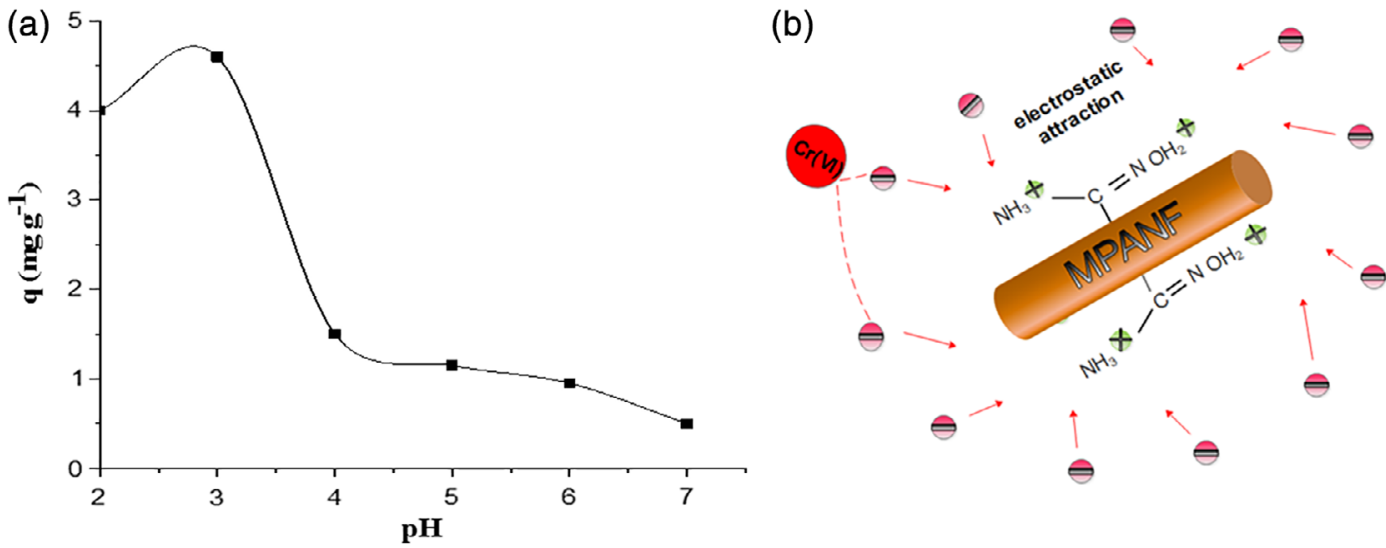

Figure 5. (a) $\mathrm{Cr}$ (VI) adsorption capacity from aqueous solutions onto AO-PANF as a function of the initial pH values and (b) schematic interpretation of electrostatic attraction between the adsorbent and adsorbate. Experimental conditions: $\mathrm{C}\left(\mathrm{NH}_{2} \mathrm{OH}\right.$. $\mathrm{HCl})=0.15 \mathrm{M}, \mathrm{C}(\mathrm{Cr}(\mathrm{VI}))=10 \mathrm{ppm}$, adsorbent dose $=0.1 \mathrm{~g}$, contact time $=1 \mathrm{~h}$, and room temperature). [Color figure can be viewed at wileyonlinelibrary.com]

According to Figure 5a, the highest adsorption capacity for chromium ions was reached $4.6 \mathrm{mg} \mathrm{g}^{-1}$ at $\mathrm{pH} 3.0$, which is consistent with previous researches [44]. While, with increasing initial $\mathrm{pH}$ values from 3.0 to 7.0 the adsorption capacities of $\mathrm{Cr}$ (VI) decreased from 4.6 to $0.5 \mathrm{mg} \mathrm{g}^{-1}$. These results can be explained as follows. Below $\mathrm{pH}<3.9$, the adsorbent surface containing amine and hydroxyl groups became protonated with increasing $\mathrm{H}^{+}$to $\left(\mathrm{NH}_{3}{ }^{+}, \mathrm{OH}_{2}^{+}\right)$and form a positively surface charge [45]. These positives charges exerts a strong electrostatic attraction with the anionic species of $\mathrm{Cr}$ (VI) present in the solution resulting on an efficient adsorption capacity of $\mathrm{HCrO}_{4}^{-}$ions which is the dominant form at $\mathrm{pH} 3.0$. The schematic diagram of electrostatic attraction between the adsorbent and adsorbate is shown in Figure 5b. However, while $\mathrm{pH}>3.9$, a decrease in adsorption capacity was noticed due to the deprotonation of functional groups resulting in a surface negatively charged. This leads on an electrostatic repulsions and competition between the $\mathrm{OH}^{-}$groups and $\mathrm{Cr}_{4} \mathrm{O}_{2}{ }^{-}$, which was hard to adsorb on adsorbent surface. Therefore, $\mathrm{pH} 3.0$ was selected as optimum $\mathrm{pH}$ for the following experiments.

\section{Effect of Adsorbent Dose}

The effect of the adsorbent dose on the Cr (VI) adsorption was evaluated by varying the initial amount of adsorbent 0.05-0.25 g, using $50 \mathrm{~mL}$ of $\mathrm{Cr}$ (VI) solutions at initial concentration of $10 \mathrm{mg} \mathrm{L}^{-1}$, at $\mathrm{pH}=3.0, T=25^{\circ} \mathrm{C}$, a contact time of $1 \mathrm{~h}$, and a stirring speed of $150 \mathrm{rpm}$ (Figure 6). The data shown in Figure 6 indicate that with increasing the adsorbent dose, the Cr (VI) adsorption capacity increased until reaching an equilibrium value. The increase of $\mathrm{Cr}$ (VI) adsorption with increasing the adsorbent dose is probably due to the availability of more adsorbent active sites [26].

\section{Effect of Contact Time}

The maximum adsorption capacity of $\mathrm{Cr}$ (VI) as function of contact time was studied in the time interval of 0-180 min, using $50 \mathrm{~mL}$ of $\mathrm{Cr}$ (VI) solutions, $0.1 \mathrm{~g}$ of adsorbent dose, at room temperature, $\mathrm{pH}=3.0$, and a stirring speed of $150 \mathrm{rpm}$ (Figure 7). As can be seen, the Cr (VI) adsorption increased rapidly during the first $15 \mathrm{~min}$, and reached the equilibrium after $60 \mathrm{~min}$ of contact time. Therefore, the time interval of 60 min was selected as the optimum contact time for the $\mathrm{Cr}$ (VI) adsorption.

\section{Thermodynamic Study}

The $\mathrm{Cr}$ (VI) adsorption onto AO-PANF under optimal conditions $\left(\mathrm{C}\left(\mathrm{NH}_{2} \mathrm{OH} . \mathrm{HCl}\right)=0.15 \mathrm{M}, \mathrm{C}(\mathrm{Cr}(\mathrm{VI}))=10 \mathrm{ppm}\right.$ and contact time $=1 \mathrm{~h}$ ) at T ranging from $5^{\circ} \mathrm{C}$ to $60^{\circ} \mathrm{C}$, is shown in Figure 8 . The adsorption capacity increases from 4.1 to $4.7 \mathrm{mg}$ $\mathrm{g}^{-1}$ with increasing the temperature from $5^{\circ} \mathrm{C}$ to $45^{\circ} \mathrm{C}$. However, at higher temperature $\left(T=60^{\circ} \mathrm{C}\right)$, a decrease in the adsorption capacity was found which may result from a possible desorption of Cr (VI) from the AO-PANF.

The thermodynamic activation parameters of AO-PANF towards $\mathrm{Cr}$ (VI), including the Gibbs free energy $\Delta G$ (KJ. $\left.\mathrm{mol}^{-1}\right)$, the enthalpy change $\Delta H\left(\mathrm{KJ} \cdot \mathrm{mol}^{-1}\right)$ and the entropy 


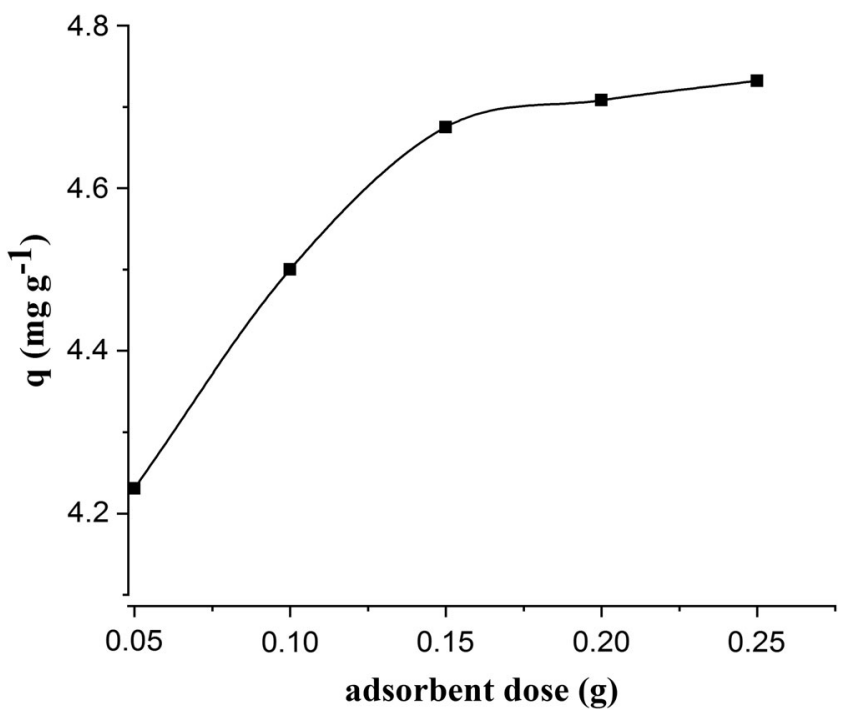

Figure 6. Effect of adsorbent dose on $\mathrm{Cr}$ (VI) adsorption from aqueous solutions onto AO-PANF $\left(\mathrm{C}\left(\mathrm{NH}_{2} \mathrm{OH} \cdot \mathrm{HCl}\right)=0.15 \mathrm{M}\right.$, $\mathrm{C}(\mathrm{Cr}(\mathrm{VI}))=10 \mathrm{ppm}, \mathrm{pH}=3.0$, contact time $=1 \mathrm{~h}$, at room temperature).

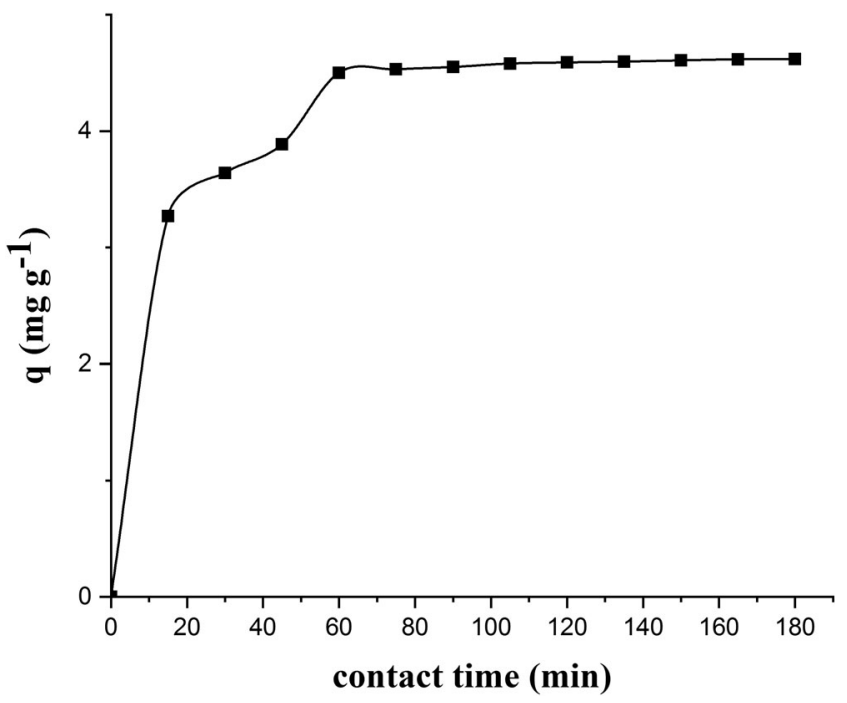

Figure 7. Effect of the contact time on the Cr (VI) adsorption from aqueous solutions onto AO-PANF. Experimental conditions: $\mathrm{C}\left(\mathrm{NH}_{2} \mathrm{OH} . \mathrm{HCl}\right)=0.15 \mathrm{M}, \mathrm{C}(\mathrm{Cr}(\mathrm{VI}))=10 \mathrm{ppm}, \mathrm{pH}=3.0$, adsorbent dose $=0.1 \mathrm{~g}$, and room temperature.

change $\Delta S\left(\mathrm{~J} \cdot \mathrm{K}^{-1} \cdot \mathrm{mol}^{-1}\right)$ were calculated using van't Hoff Equations [46]:

$\Delta G=-R T \ln K_{d}$

$\operatorname{In} K_{d}=-\frac{\Delta H}{R T}+\frac{\Delta S}{R}$

Where $K_{d}$ is the equilibrium constant, $R$ is the gas constant (8.314 J.mol. ${ }^{-1} \cdot \mathrm{K}^{-1}$ ) and $T$ is the Kelvin temperature. The values of $\Delta H$ and $\Delta S$ were determined from the plot of $\ln K_{d}$ versus $1 / T$, and summarized in Table 2 .

According to the Table 2 , the negative values of $\Delta G$ indicate the spontaneity nature of the adsorption process. The augmentation of $\Delta G$ value after $318 \mathrm{~K}$ showed that, at higher temperatures, the adsorption process become unfavorable and required

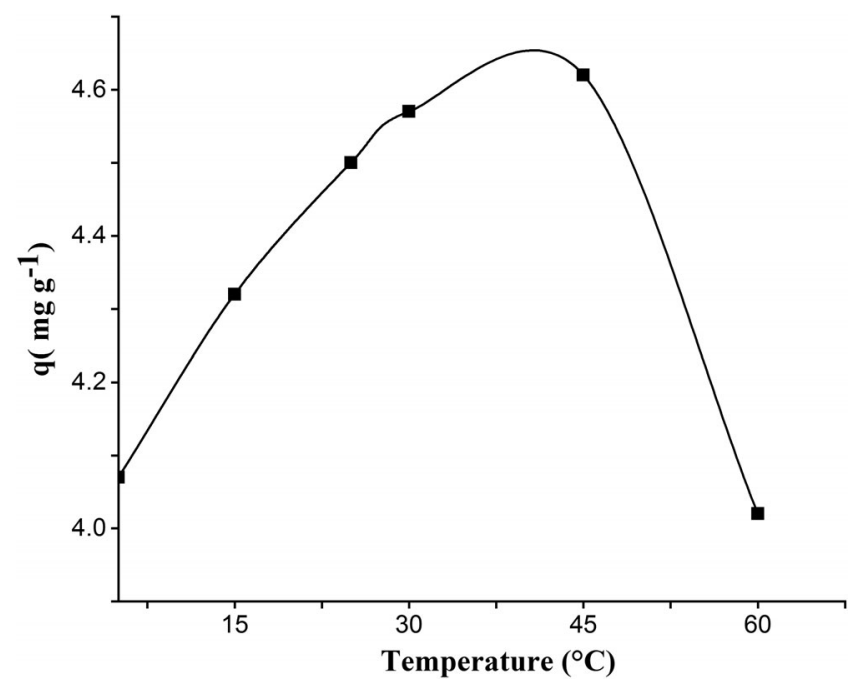

Figure 8. Effect of temperature on the $\mathrm{Cr}$ (VI) adsorption from aqueous solutions onto AO-PANF. Experimental conditions: $\mathrm{C}$ $\left(\mathrm{NH}_{2} \mathrm{OH} . \mathrm{HCl}\right)=0.15 \mathrm{M}, \mathrm{C}(\mathrm{Cr}(\mathrm{VI}))=10 \mathrm{ppm}, \mathrm{pH}=3.0$, adsorbent dose $=0.1 \mathrm{~g}$, and contact time $=1 \mathrm{~h}$.

Table 2. Thermodynamics parameters for $\mathrm{Cr}$ (VI) adsorption by AO-PANF.

\begin{tabular}{|c|c|c|c|}
\hline$\overline{T(K)}$ & $\overline{\Delta G\left(\mathrm{KJ} \cdot \mathrm{mol}^{-1}\right)}$ & $\overline{\Delta H\left(K J \cdot \mathrm{mol}^{-1}\right)}$ & $\Delta S\left(K_{.} J^{-1} \cdot \mathrm{mol}^{-1}\right)$ \\
\hline 278 & -13.14 & 30.25 & 163.92 \\
\hline 288 & -17.14 & & \\
\hline 303 & -21.80 & & \\
\hline 318 & -26.64 & & \\
\hline 333 & -19.23 & & \\
\hline
\end{tabular}

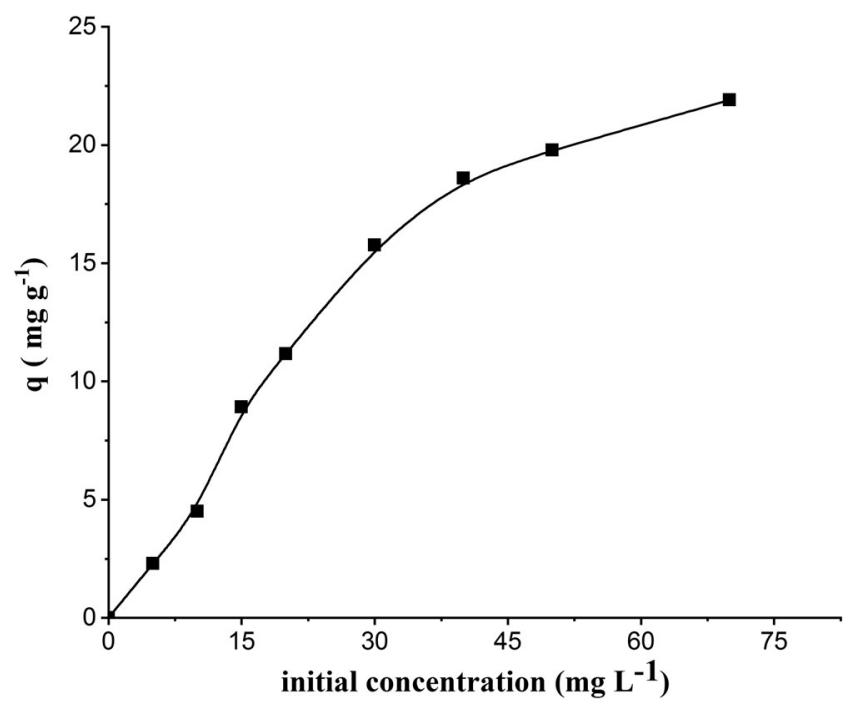

Figure 9. Effect of initial concentration on Cr (VI) adsorption from aqueous solutions onto AO-PANF. Experimental conditions: $\mathrm{C}\left(\mathrm{NH}_{2} \mathrm{OH} . \mathrm{HCl}\right)=0.15 \mathrm{M}, \mathrm{pH}=3.0$, adsorbent dose $=0.1 \mathrm{~g}$, contact time $=1 \mathrm{~h}$, and room temperature).

more energy [47]. The $\Delta H$ value for Cr (VI) $30.25>40$ mention that the adsorption process is physical [48]. Furthermore, the positive value of $\Delta S\left(163.92 \mathrm{~K} . \mathrm{J}^{-1} \cdot \mathrm{mol}^{-1}\right)$ indicate the feasibility of the adsorption and suggest an increase of the randomness at the solid liquid -interface during the fixation of $\mathrm{Cr}$ (VI) onto AO-PAN [49]. 

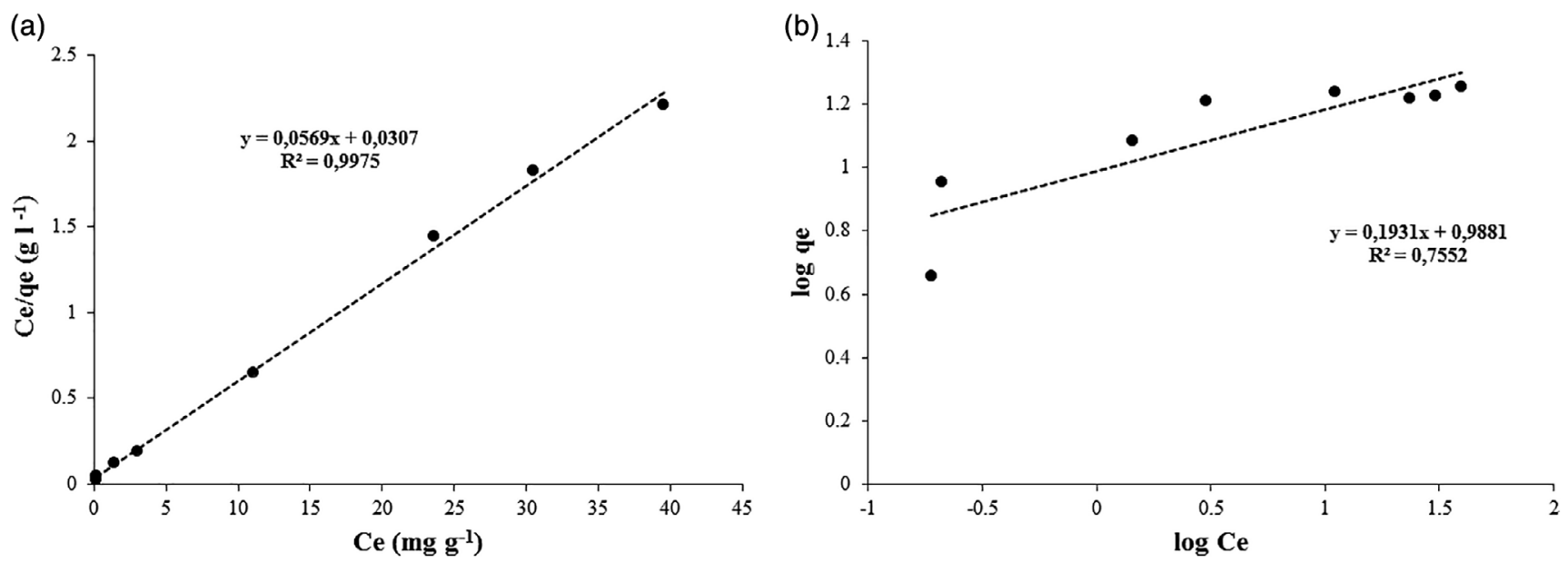

Figure 10. (a) Langmuir and (b) Freundlich plot of $\mathrm{Cr}$ (VI) adsorption onto AO-PANF. Experimental conditions: $\mathrm{C}\left(\mathrm{NH}_{2} \mathrm{OH}\right.$. $\mathrm{HCl})=0.5 \mathrm{M}, \mathrm{pH}=3.0$, adsorbent dose $=0.1 \mathrm{~g}$, and room temperature.

Table 3. Langmuir and Freundlich constants for Cr (VI) adsorption on AO-PANF.

\begin{tabular}{|c|c|c|c|c|c|c|}
\hline \multicolumn{4}{|c|}{ Langmuir } & \multicolumn{3}{|c|}{ Freundlich } \\
\hline $\begin{array}{l}q_{m} \\
\left(\mathrm{mg} \cdot \mathrm{g}^{-1}\right) \\
\end{array}$ & $\left.\begin{array}{c}K_{L} \\
(\text { L.mg } \\
-1\end{array}\right)$ & $R^{2}$ & $\boldsymbol{R}_{L}$ & $\begin{array}{c}K_{F} \\
\left(\mathrm{mg} \cdot \mathrm{g}^{-1}\right) \\
\end{array}$ & $\frac{1}{n}$ & $R^{2}$ \\
\hline 32.57 & 0.54 & 0.997 & 0.20 & 9.729 & 0.193 & 0.755 \\
\hline
\end{tabular}

Effect of Initial Concentration of $\mathrm{Cr}(\mathrm{VI})$

The adsorption capacity of $\mathrm{Cr}(\mathrm{VI})$, at various initial concentrations, is shown in Figure 9. The experiments were conducted using Cr (VI) initial concentration varying from 5 to $70 \mathrm{mg} \mathrm{L}^{-1}$, an adsorbent dose of $0.1 \mathrm{~g}$, contact time of $1 \mathrm{~h}$, at room temperature, and a stirring speed of $150 \mathrm{rpm}$. Figure 9 shows that with an increase of initial concentration, the adsorption capacity increased also. The increase of adsorption capacity with increasing of initial concentration is due to the increase of driving force of the concentration gradient [15].

\section{Isotherm Study}

The adsorption isotherms describe the interaction between the adsorbents and the concentrations of metal ions in solutions at a constant temperature. Langmuir and Freundlich isotherm models are the two important isotherm models employed to analyze the equilibrium sorption data and to evaluate the nature of adsorption of metal ions onto adsorbent [50]. Equilibrium adsorption experiments were carried out at $\mathrm{pH} 3.0$, at a constant temperature with increasing initial concentration of $\mathrm{Cr}$ (VI) in the solutions from 5 to $70 \mathrm{mg} \mathrm{g}^{-1}$, and the results are presented in Figure 10. The Langmuir model describes a monolayer adsorption on a uniform surface of adsorbent with homogenous distributions of the adsorption sites without interaction force between molecules. The linear equation is given as follows [51]:

$\frac{C_{e}}{q_{e}}=\frac{C_{e}}{q_{m}}+\frac{1}{K_{L} q_{m}}$

Where $C_{e}$ is the equilibrium concentrations of $\mathrm{Cr}$ (VI) ions in the solution $\left(\mathrm{mg} \mathrm{L}^{-1}\right), q_{e}$ is the amount of $\mathrm{Cr}$ (VI) adsorbed onto AO-PANF $\left(\mathrm{mg} \mathrm{g}^{-1}\right), q_{m}$ is the maximum adsorption capacity $\left(\mathrm{mg} \mathrm{g}^{-1}\right)$, and $K_{L}$ is the Langmuir constant related to the energy of adsorption $\left(\mathrm{L} \mathrm{mg}^{-1}\right)$. The values of $q_{m}$ and $K_{L}$ was determined using the plot of $C_{e} / q_{e}$ versus $C_{e}$ (Figure 10a).
Another Langmuir parameters, the dimensionless separation factor $R_{L}$, was calculated using the following Equation [52]:

$R_{L}=\frac{1}{1+K_{L} C_{0}}$

Where $C_{0}$ is the initial concentration of $\mathrm{Cr}$ (VI) in solution. The $R_{L}$ value is classified into different categories. In case $R_{L}=0$ the monolayer adsorption is irreversible, $0<R_{L}<1$ the adsorption is favorable, $R_{L}=1$ the adsorption is linear and $R_{L}>1$ the adsorption is unfavorable [53].

Freundlich model isotherm describes the multilayers adsorption of metal ions on a heterogeneous surface of the adsorbent. The linear equation is as follows [51]:

$\log q_{e}=\log K_{F} \frac{1}{n} \log C_{e}$

Where $K_{F}\left[\left(\mathrm{mg} \mathrm{g}^{-1}\right)\left(\mathrm{L} \mathrm{mg}^{-1}\right)^{1 / n}\right]$ and $\mathrm{n}$ are the Freundlich constant representing the adsorption capacity and the adsorption intensity, respectively [54]. The values of theses parameters are determined by plotting $\log \mathrm{q}_{\mathrm{e}}$ as a function of $\log C_{e}$ (Figure $10 \mathrm{~b}$ ).

Table 3 displayed the constant parameters and the correlation coefficient of $R^{2}$ of Langmuir and Freundlich isotherm models. The values of correlation coefficients in Table 3 show that the $\mathrm{Cr}$ (VI) in the AO-PANF were fitter better with the Langmuir model $\left(R^{2}=0.997\right)$ compared to the Freundlich model $\left(R^{2}=0.755\right)$, confirming that $\mathrm{Cr}(\mathrm{VI})$ sorption mechanism onto AO-PANF surface is monolayer adsorption. The values of maximum adsorption capacity $q_{m}$ of $\mathrm{Cr}(\mathrm{VI})$, calculating using Langmuir equation was found to be $32.57 \mathrm{mg} \mathrm{g}^{-1}$, relatively greater than others adsorbents used [54].In addition, the calculated $\mathrm{R}_{\mathrm{L}}$ values was 0.20 indicating that the $\mathrm{Cr}(\mathrm{VI})$ adsorption onto AO-PANF is favorable.

\section{Desorption Study}

The capacities of AO-PANF to be regenerated after the $\mathrm{Cr}$ (VI) adsorption using various desorbing agents $(\mathrm{NaOH}, \mathrm{NaCl}$, 
(a)

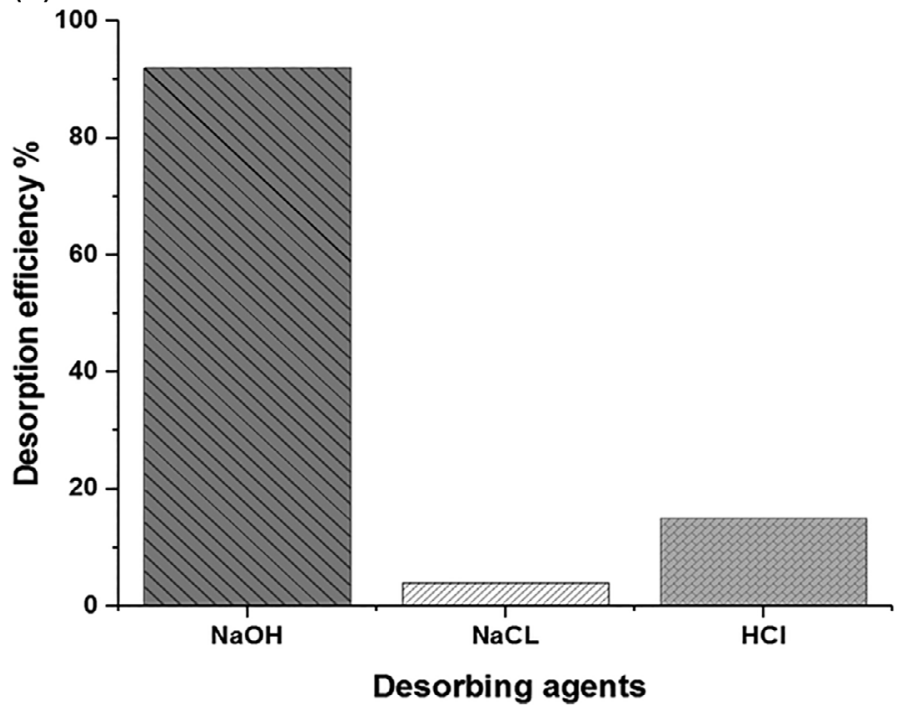

(b)

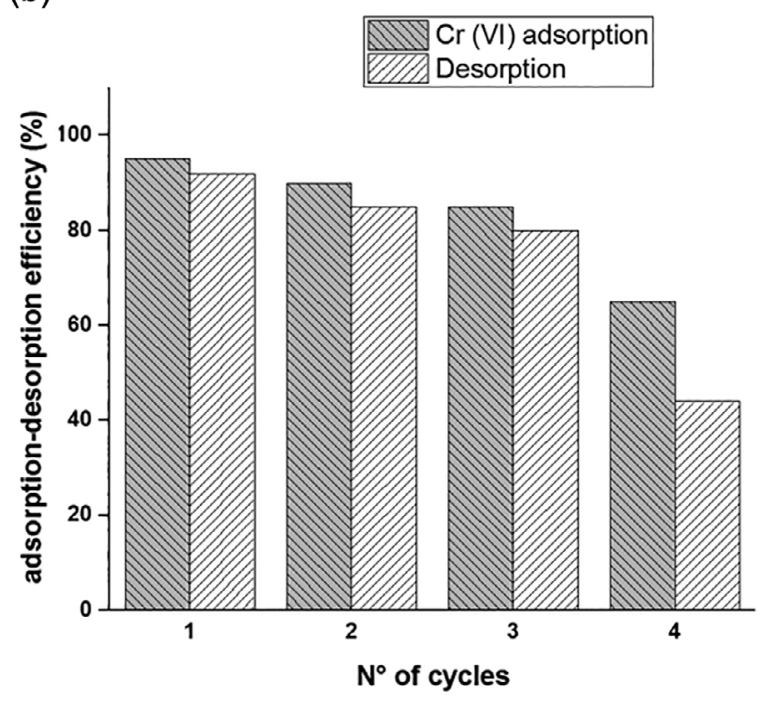

Figure 11. (a) Desorption efficiency of Cr (VI) from AO-PANF using different desorbing agents, (b) adsorption-desorption cycles of AO-PANF. Experimental conditions: $\mathrm{C}$ (desorbing agents) $=0.5 \mathrm{M}, \mathrm{C}(\mathrm{Cr}(\mathrm{VI}))=10 \mathrm{ppm}$, contact time $=16 \mathrm{~h}$ and room temperature.

Table 4. Summary of different results obtained during the present study.

\begin{tabular}{|c|c|c|c|c|c|}
\hline $\begin{array}{l}\mathrm{NH}_{2} \text { OH.HCl } \\
\text { (M) }\end{array}$ & $\begin{array}{c}\text { PANF modification } \\
\text { time (min) }\end{array}$ & $\begin{array}{c}C_{n}(\%) \\
\text { Equation (1) }\end{array}$ & $\begin{array}{l}\text { Adsorption } \\
\text { time (hour) }\end{array}$ & $\begin{array}{c}\% R \\
\text { Equation (2) }\end{array}$ & $\begin{array}{c}q\left(\mathrm{mg} \mathrm{g}^{-1}\right) \\
\text { Equation (3) }\end{array}$ \\
\hline \multirow[t]{4}{*}{0.05} & 30 & 4.01 & 1 & 5.17 & 2.57 \\
\hline & 60 & 6.42 & & 39.42 & 9.62 \\
\hline & 90 & 19.27 & & 43.47 & 11.64 \\
\hline & 120 & 22.48 & & 60.07 & 19.90 \\
\hline \multirow[t]{4}{*}{0.1} & 30 & 5.62 & & 16.41 & 8.16 \\
\hline & 60 & 16.06 & & 59.10 & 19.42 \\
\hline & 90 & 20.8 & & 64.55 & 22.13 \\
\hline & 120 & 32.12 & & 73.37 & 26.52 \\
\hline \multirow[t]{2}{*}{0.15} & 30 & 6.42 & & 18.08 & 9.00 \\
\hline & 60 & 33.7 & & 92.19 & 23.89 \\
\hline
\end{tabular}

and $\mathrm{HCl}$ )with concentration of $0.5 \mathrm{M}$, are depicted in Figure 11a. The best results were obtained by using $0.5 \mathrm{M}$ of $\mathrm{NaOH}$ for a contact time of $16 \mathrm{~h}$, and allowed the recovery in water of $>90 \%$ of adsorbed $\mathrm{Cr}$ (VI). After the desorption experiment with $0.5 \mathrm{M}$ of $\mathrm{NaOH}$, the adsorbent was filtrated from solution, washed with distillated water, dried at $60^{\circ} \mathrm{C}$ and reuse for $\mathrm{Cr}$ (VI) adsorption. Figure $11 \mathrm{~b}$ showed the adsorptiondesorption cycles of AO-PANF. It can be seen that the $\mathrm{Cr}$ (VI) removal efficiency was kept nearby of 90\% after three cycles. Then, the removal percentage decreased significantly with subsequent adsorption-desorption cycles. It can be due to the accumulation of incomplete desorption of $\mathrm{Cr}$ (VI) from the AO-PANF surfaces. The results concluded that the AO-PANF is reusable and effective for three adsorption-desorption cycles.

\section{Summary of the Results}

Table 4 shows different results and values obtained in this study. Note that the adsorption values mentioned in this table relate to the values obtained under optimal conditions.

\section{CONCLUSIONS}

The surface modification of PANF, consisting in the conversion of the fibers nitrile groups into amidoxime groups, produced a new efficient adsorbent for $\mathrm{Cr}$ (VI) removal from aqueous solutions. The PANF functionalization process was achieved by using various $\mathrm{NH}_{2} \mathrm{OH} . \mathrm{HCl}$ concentrations. Optimum conditions for the PANF modification process lead to the highest nitrile groups conversion. The resulting AO-PANF provides a great ability to remove $\mathrm{Cr}$ (VI) ions from aqueous solutions. Optimal conditions leading to highest $\mathrm{Cr}$ (VI) removal from aqueous solutions were found. The Cr (VI) adsorption capacity was found to increase with increasing the temperature. At temperatures higher than $45^{\circ} \mathrm{C}$, a decrease in the adsorbed amount was observed. The maximum sorption capacity was $32.52 \mathrm{mg} \mathrm{g}^{-1}$ under optimal conditions. Finally, the adsorbed $\mathrm{Cr}$ (VI) ion on the AO-PANF was found to be easily recovered using $\mathrm{NaOH}$ desorbing agents and the adsorbent was reused for three adsorption-desorption cycles.

\section{LITERATURE CITED}

1. Fu, F., \& Wang, Q. (2011). Removal of heavy metal ions from wastewaters: a review, Journal of Environmental Management, 92, 407-418.

2. Gokila, S., Gomathi, T., Sudha, P.N., \& Anil, S. (2017). Removal of the heavy metal ion chromium (VI) using Chitosan and Alginate nanocomposites, International Journal of Biological Macromolecules, 104, 1459-1468.

3. Kan, C.C., Ibe, A.H., Rivera, K.K.P., Arazo, R.O., \& de Luna, M. D.G. (2017). Hexavalent chromium removal from aqueous solution by adsorbents synthesized from groundwater 
treatment residuals, Sustainable Environment Research, 27, $163-171$.

4. Nam, A., su Choi, U., Yun, S.T., Choi, J.W., Park, J.A., \& Lee, S.H. (2018). Evaluation of amine-functionalized acrylic ion exchange fiber for chromium (VI) removal using flowthrough experiments modeling and real wastewater. Journal of Industrial and Engineering Chemistry, Korean Society of Industrial Engineering Chemistry, 66, 187-195.

5. Jobby, R., Jha, P., Yadav, A.K., \& Desai, N. (2018). Biosorption and biotransformation of hexavalent chromium [Cr (VI)]: a comprehensive review, Chemosphere, 207, 255-266.

6. Bhowmik, K.L., Kanmani, M., Deb, A., Debnath, A., Nath, R. K., \& Saha, B. (2018). Mesoporous iron-manganese magnetic bimetal oxide for efficient removal of $\mathrm{Cr}$ (VI) from synthetic aqueous solution, Applied Mechanics and Materials, $877,33-38$.

7. Rajput, S., Pittman, C.U. Jr., \& Mohan, D. (2016). Magnetic magnetite $\left(\mathrm{Fe}_{3} \mathrm{O}_{4}\right)$ nanoparticle synthesis and applications for lead $\left(\mathrm{Pb}^{2+}\right)$ and chromium $\left(\mathrm{Cr}^{6+}\right)$ removal from water, Journal of Colloid and Interface Science, 468, 334-346.

8. Lytras, G., Lytras, C., Argyropoulou, D., Dimopoulos, N., Malavetas, G., \& Lyberatos, G. (2017). A novel two-phase bioreactor for microbial hexavalent chromium removal from wastewater, Journal of Hazardous Materials, 336, 41-51.

9. Fang, L., Li, L., Qu, Z., Xu, H., Xu, J., \& Yan, N. (2018). A novel method for the sequential removal and separation of multiple heavy metals from wastewater, Journal of Hazardous Materials, 342, 617-624.

10. Bhunia, P., Chatterjee, S., Rudra, P., \& De, S. (2018). Chelating polyacrylonitrile beads for removal of lead and cadmium from wastewater, Separation and Purification Technology, 193, 202-213.

11. Debnath, A., Deb, K., Chattopadhyay, K.K., \& Saha, B. (2016). Methyl orange adsorption onto simple chemical route synthesized crystalline $\alpha$-Fe2O3 nanoparticles: kinetic, equilibrium isotherm, and neural network modeling, Desalination and Water Treatment, 57, 13549-13560.

12. Bode-Aluko, C.A., Pereao, O., Ndayambaje, G., \& Petrik, L. (2017). Adsorption of toxic metals on modified polyacrylonitrile nanofibres: a review, Water, Air, and Soil Pollution, $228,35$.

13. Cho, D.W., Chon, C.M., Kim, Y., Jeon, B.H., Schwartz, F. W., Lee, E.S., \& Song, H. (2011). Adsorption of nitrate and Cr (VI) by cationic polymer-modified granular activated carbon, Chemical Engineering Journal, 175, 298-305.

14. Jain, M., Garg, V.K., \& Kadirvelu, K. (2010). Adsorption of hexavalent chromium from aqueous medium onto carbonaceous adsorbents prepared from waste biomass, Journal of Environmental Management, 91, 949-957.

15. Malkoc, E., Nuhoglu, Y., \& Dundar, M. (2006). Adsorption of chromium (VI) on pomace-an olive oil industry waste: batch and column studies, Journal of Hazardous Materials, 138, 142-151.

16. Rao, R.A., \& Rehman, F. (2010). Adsorption studies on fruits of Gular (Ficus glomerata): removal of Cr (VI) from synthetic wastewater, Journal of Hazardous Materials, 181, 405-412.

17. Zimmermann, A.C., Mecabô, A., Fagundes, T., \& Rodrigues, C.A. (2010). Adsorption of Cr (VI) using Fe-cross linked chitosan complex (Ch-Fe), Journal of Hazardous Materials, 179, 192-196.

18. Zhao, R., Li, X., Sun, B., Ji, H., \& Wang, C. (2017). Diethylene triamine-assisted synthesis of amino-rich hydrothermal carbon-coated electro spun polyacrylonitrile fiber adsorbents for the removal of $\mathrm{Cr}$ (VI) and 2, 4-dichlorophenoxyacetic acid, Journal of Colloid and Interface Science, 487, 297-309.

19. Debnath, A., Deb, K., Das, N.S., Chattopadhyay, K.K., \& Saha, B. (2016). Simple chemical route synthesis of Fe2O3 nanoparticles and its application for adsorptive removal of Congo red from aqueous media: artificial neural network modeling, Journal of Dispersion Science and Technology, 37, 775-785.

20. Sakr, F., Sennaoui, A., Dinne, M., Alahiane, S., Bakas, I., Belmoden, M., \& Assabbane, A. (2017). Application in chromium (VI) removal of natural and dried cactus, Ciência \& Tecnologia dos Materiais, 29, 145-152.

21. Wu, J., Zhang, H., He, P.J., Yao, Q., \& Shao, L.M. (2010). Cr (VI) removal from aqueous solution by dried activated sludge biomass, Journal of Hazardous Materials, 176, 697-703.

22. Saha, B., \& Orvig, C. (2010). Biosorbents for hexavalent chromium elimination from industrial and municipal effluents, Coordination Chemistry Reviews, 254, 2959-2972.

23. Zhang, H., Tang, Y., Cai, D., Liu, X., Wang, X., Huang, Q., \& $\mathrm{Yu}, \mathrm{Z}$. (2010). Hexavalent chromium removal from aqueous solution by algal bloom residue derived activated carbon: equilibrium and kinetic studies, Journal of Hazardous Materials, $181,801-808$.

24. Loukidou, M.X., Zouboulis, A.I., Karapantsios, T.D., \& Matis, K.A. (2004). Equilibrium and kinetic modeling of chromium (VI) biosorption by Aeromonas caviae, Colloids and Surfaces A: Physicochemical and Engineering Aspects, 242, 93-104.

25. Fu, F., Ma, J., Xie, L., Tang, B., Han, W., \& Lin, S. (2013). Chromium removal using resin supported nanoscale zerovalent iron, Journal of Environmental Management, 128, 822-827.

26. Enniya, I., Rghioui, L., \& Jourani, A. (2018). Adsorption of hexavalent chromium in aqueous solution on activated carbon prepared from apple peels, Sustainable Chemistry and Pharmacy, 7, 9-16.

27. Abdouss, M., Shoushtari, M.A., Haji, A., \& Moshref, B. (2012). Fabrication of chelating diethylenetriaminated PAN, micro-and nano-fibers for heavy metal removal, Chemical Industry and Chemical Engineering Quarterly/CICEQ, 18, $27-34$.

28. Xu, G., Zhao, Y., Hou, L., Cao, J., Tao, M., \& Zhang, W. (2017). A recyclable phosphinic acid functionalized polyacrylonitrile fiber for selective and efficient removal of $\mathrm{Hg} 2+$, Chemical Engineering Journal, 325, 533-543.

29. Nataraj, S.K., Yang, K.S., \& Aminabhavi, T.M. (2012). Polyacrylonitrile-based nanofibers-a state-of-the-art, review, Progress in Polymer Science, 37, 487-513.

30. Tham, H.M., Wang, K.Y., Hua, D., Japip, S., \& Chung, T.S. (2017). From ultrafiltration to nanofiltration: Hydrazine cross-linked polyacrylonitrile hollow fiber membranes for organic solvent nanofiltration, Journal of Membrane Science, 542, 289-299.

31. Kharaghani, D., Khan, M., Shahzad, A., Inoue, Y., Yamamoto, T., Rozet, S., Tamada, Y., \& Kim, I. (2018). Preparation and in-vitro assessment of hierarchal organized antibacterial breath mask based on Polyacrylonitrile/silver (PAN/AgNPs) nanofiber, Nanomaterials, 8, 461.

32. Ji, L., \& Zhang, X. (2008). Ultrafine polyacrylonitrile/silica composite fibers via electro spinning, Materials Letters, 62, 2161-2164.

33. He, C., Liu, J., Li, J., Zhu, F., \& Zhao, H. (2018). Blending based polyacrylonitrile/poly (vinyl alcohol) membrane for rechargeable lithium ion batteries, Journal of Membrane Science, 560, 30-37.

34. Shi, X.L., Hu, Q., Wang, F., Zhang, W., \& Duan, P. (2016). Application of the polyacrylonitrile fiber as a novel support for polymer-supported copper catalysts in terminal alkyne homocoupling reactions, Journal of Catalysis, 337, 233-239.

35. Koutsonas, S. (2017). Electrical conductivity of degraded polyacrylonitrile powder by microwave irradiation for super capacitor devices or other mobile applications, Materials Letters, 193, 203-205.

36. Agcaoili, A.R., Herrera, M.U., Futalan, C.M., \& Balela, M.D. L. (2017). Fabrication of polyacrylonitrile-coated kapok hollow microtubes for adsorption of methyl orange and 
$\mathrm{Cu}$ (II) ions in aqueous solution, Journal of the Taiwan Institute of Chemical Engineers, 78, 359-369.

37. Horzum, N., Shahwan, T., Parlak, O., \& Demir, M.M. (2012). Synthesis of amidoximated polyacrylonitrile fibers and its application for sorption of aqueous uranyl ions under continuous flow, Chemical Engineering Journal, 213, 41-49.

38. Lutfor, M.R., \& Mashitah, M.Y. (2011). Synthesis of poly (hydroxamic acid)-poly (amidoxime) chelating ligands for removal of metals from industrial wastewater, Journal of Chemistry, 8, 1038-1043.

39. Zhang, Y., Ren, Y., Liu, X., Huo, T., \& Qin, Y. (2018). Preparation of durable flame retardant PAN fabrics based on amidoximation and phosphorylation, Applied Surface Science, 428, 395-403.

40. Elwakeel, K.Z., El-Bindary, A.A., Kouta, E.Y., \& Guibal, E. (2018). Functionalization of polyacrylonitrile/Na-Y-zeolite composite with amidoxime groups for the sorption of $\mathrm{Cu}$ (II), Cd (II) and $\mathrm{Pb}$ (II) metal ions, Chemical Engineering Journal, 332, 727-736.

41. Peng, Y., Guo, F., Wen, Q., Yang, F., \& Guo, Z. (2017). A novel polyacrylonitrile membrane with a high flux for emulsified oil/water separation, Separation and Purification Technology, 184, 72-78.

42. Pouretedal, H.R., \& Sadegh, N. (2014). Effective removal of amoxicillin, cephalexin, tetracycline and penicillin $G$ from aqueous solutions using activated carbon nanoparticles prepared from vine wood, Journal of Water Process Engineering, 1, 64-73.

43. Lu, F., Huang, C., You, L., Yin, Y., \& Zhang, Q. (2017). Cross-linked amino konjac glucomannan as an ecofriendly adsorbent for adsorption of $\mathrm{Cr}$ (VI) from aqueous solution, Journal of Molecular Liquids, 247, 141-150.

44. Zhu, N., Yan, T., Qiao, J., \& Cao, H. (2016). Adsorption of arsenic, phosphorus and chromium by bismuth impregnated biochar: Adsorption mechanism and depleted adsorbent utilization, Chemosphere, 164, 32-40.

45. Yan, E., Cao, M., Ren, X., Jiang, J., An, Q., Zhang, Z., Gao, J., Yang, X., \& Zhang, D. (2018). Synthesis of $\mathrm{Fe}_{3} \mathrm{O}_{4}$ nanoparticles functionalized polyvinyl alcohol/chitosan magnetic composite hydrogel as an efficient adsorbent for chromium (VI) removal, Journal of Physics and Chemistry of Solids, 121, 102-109.
46. Debnath, A., Bera, A., Chattopadhyay, K.K., \& Saha, B. (2017). Facile additive-free synthesis of hematite nanoparticles for enhanced adsorption of hexavalent chromium from aqueous media: Kinetic, isotherm, and thermodynamic study, Inorganic and Nano-Metal Chemistry, 47, 1605-1613.

47. Bhowmik, K.L., Debnath, A., Nath, R.K., \& Saha, B. (2017). Synthesis of $\mathrm{MnFe}_{2} \mathrm{O}_{4}$ and $\mathrm{Mn}_{3} \mathrm{O}_{4}$ magnetic nanocomposites with enhanced properties for adsorption of $\mathrm{Cr}$ (VI): artificial neural network modeling, Water Science and Technology., 76, 3368-3378.

48. Lim, Y.S., \& Kim, J.H. (2017). Isotherm, kinetic and thermodynamic studies on the adsorption of 13-dehydroxybaccatin III from Taxus chinensis onto Sylopute, The Journal of Chemical Thermodynamics, 115, 261-268.

49. Elabbas, S., Mandi, L., Berrekhis, F., Pons, M.N., Leclerc, J. P., \& Ouazzani, N. (2016). Removal of Cr (III) from chrome tanning wastewater by adsorption using two natural carbonaceous materials: eggshell and powdered marble, Journal of Environmental Management, 166, 589-595.

50. Deng, S., Wang, P., Zhang, G., \& Dou, Y. (2016). Polyacrylonitrile-based fiber modified with thiosemicarbazide by microwave irradiation and its adsorption behaviour for Cd (II) and Pb (II), Journal of Hazardous Materials, 307, 64-72.

51. Bhowmik, K.L., Debnath, A., Nath, R.K., Das, S., Chattopadhyay, K.K., \& Saha, B. (2016). Synthesis and characterization of mixed phase manganese ferrite and hausmannite magnetic nanoparticle as potential adsorbent for methyl orange from aqueous media: artificial neural network modeling, Journal of Molecular Liquids, 219, 1010-1022.

52. Singh, K., Shah, C., Dwivedi, C., Kumar, M., \& Bajaj, P.N. (2013). Study of uranium adsorption using amidoximated polyacrylonitrile-encapsulated macroporous beads, Journal of Applied Polymer Science, 127, 410-419.

53. Bhowmik, B., L, K., Deb, K., Bera, A., Debnath, A., \& Saha, B. (2018). Interaction of anionic dyes with polyaniline implanted cellulose: Organic $\pi$-conjugated macromolecules in environmental applications, Journal of Molecular Liquids, 261, 189-198.

54. Hyder, A.G., Begum, S.A., \& Egiebor, N.O. (2015). Adsorption isotherm and kinetic studies of hexavalent chromium removal from aqueous solution onto bone char, Journal of Environmental Chemical Engineering, 3, 1329-1336. 